\title{
The Effect of Corporate Governance on The Performance of Firms: A study on Pharmaceutical Sector of Pakistan
}

\author{
Abid Rasheed \\ Lecturer \\ School of Accounting and Finance, University of Central Punjab. \\ abid.rasheed@ucp.edu.pk \\ Hafsa Zaki \\ Ms Scholar \\ School of Accounting and Finance, University of Central Punjab.
}

\begin{abstract}
This article focuses on the effect of corporate governance on pharmaceutical sector of Pakistan. This is the quantitative study and it is based on the nine listed pharmaceutical companies of Pakistan. Seven variables are chosen and only one variable is dependent that is return on asset and other six variables are independent. This study also identifies the importance of corporate governance and how it affects the performance of the firm. It has been observed that only one variable which is Board composition has a significant effect on the performance of pharma sector while the other variables which are Board size, Company size, CEO duality, Independent directors and Dependent directors has no significant effect on the performance of pharma sector. Through tests, it is proved that pharma sector is not giving as much importance to corporate governance which is required from the sector.
\end{abstract}

Keywords: Corporate governance, composition of board, firm performance

\section{Introduction}

Corporate governance plays a vital role in the performance of the firm. Before some years, there was no importance given to this sector but now it is the most important part of the organization. The word "governance" is driven from the Greek word Kybeman, meaning to "Steer, guide or Govern" and the term corporate governance has both narrow and broad definitions. In narrow definition it shows the relationship between managers, directors and shareholders while in broad definition, it is the combination of laws, regulations, listing rules, generate profit and meet both legal and social obligations (Yasser, 2011). The main aim of the corporate governance is to manage the principles and rules of organization which can help the manager to achieve their ultimate objective. The ultimate objective of any organization is to maximize the wealth of shareholders. Manager's works like an agent and they are appointed by shareholders as an agent so the

The current issue and full text archive of this journal is available at www.jraspublications.org/index.php/JRAS/issue/archive Journal of Research in Administrative Sciences (JRAS)

VII(II), 14-18, ISSN: 2664-2433 agency relationship develops automatically. (Gillan, 2006) Stated that boards of directors are the responsible to manage and to run management and they are the main theme of the internal corporate governance.

This article tells about how corporate governance effects on the performance of the firm as the finance is the blood of an organization same as without corporate governance, firm cannot work efficiently. This study is done on the nine listed pharmaceutical companies of Pakistan. These companies are listed on the stock exchange of Pakistan and having well known history in pharma sector. There are seven variables which are used in this study. One variable is dependent and that is ROA (return on asset) and the other six variables are independent variables that are: board composition, board size, CEO duality, company size, dependent directors and independent directors. 


\section{Abid Rasheed, Hafsa Zaki}

There is gap exists in pharmaceutical sector so to address this gap pharma sector was chosen to check the effect of corporate governance on performance of pharma sector. To address this gap seven listed pharma companies are chosen to check whether corporate governance has any effect on the performance or not. The objective of this article is to analysis the effect of corporate governance on the pharmaceutical companies of Pakistan and to check, is pharma sector knows about the importance of corporate governance or not.

\section{Literature Review}

The purpose of this article is to analyze how corporate governance is affecting the firm performance. The practice of corporate governance in the firm is giving the competitive edge to the organizations and it is helping in making a position in global market. (Mashayekhi \& Bazaz, 2008) If corporate governance is stable so it will build market confidence and firm will stay stable in all type of problems. Many countries believe that good corporate governance will help in improving the economic circumstances. There must be compatibility between the global standards and corporate governance. To survive in the global market, firms have to give importance to corporate governance. It is also mentioned that there is the agency relationship which shows that directors are working as an agent of the shareholders and shareholders are the owner of the organization they have right to ask the performance of the organization and directors are accountable in front of the shareholder. Shareholder held the relationship of principle and principles cover five areas: the rights of shareholders, the equitable treatment of shareholders, the role of stakeholders, disclosure and transparency, the responsibilities of the board. (John \& L., 1998) Stated that is a mechanism which allocate authority among the employees and also control the decision making process in the top management of the firm.

(Brown, Robinson, \& Caylor, 2007) Corporate governance received great attention due to the case of Enron and other high profile scandals, it also forces the United State to change their regulations and they introduce a strict codified law which is Sarbanes-Oxley Act of 2002. Due to this new codified law, system get trickier and it just eliminate the maximum chances of fraud. Law increased the cost of doing business which is ultimately affecting the shareholder return. (Bhagat \& Bolton, 2007) There are three alternative ways of understanding the relationship between the return performances of companies with strong shareholder rights. First, results could be sample-period specific and second is risk adjustment might not done effectively, and in third the relation between performance and corporate governance might be endogenous raising doubts about the causality explanation. (Baek, Kang, \& Park, 2004) Current research reveals the importance of corporate governance in the country and it informed that without following corporate governance, an organization cannot be stable in the market. The difference between the structure of laws and their enforcement and financial market development, that such developments actually satisfy the investor about his investment.

In corporate governance, the board of directors is the critical element in a firm. They have two major functions, first they hire fire and compensate managers and the other one function is to advise managers and gave them strategic decisions. If directors are performing these functions effectively so it will increase the effectiveness of board and their decision making process. (Masulis, Wang, \& Xie, 2010) Stated that they are focusing on an interesting class of directors these are foreign independent directors who are not the national of the country where the firm is working. Foreign directors can be less effective due to some reasons, directors who live outside the country they cannot attend meetings frequently so they cannot take the active part in the management and in decision making process of a firm. They cannot get the quality of information about the organization so it will affect their performance for firm.

(Core, Holthausen, \& Larcker, 1999) Observed that there is difference between the level of CEO compensation and the quality of firms' corporate governance, and if the firm has weaker governance structure so it have poorer future performance. The firm with weaker governance cannot sustain in the market because now everyone knows the importance of corporate governance and workers like to work according to the well-defined process. (Crystal, 1991) Argued that board of directors cannot work freely because they are appointed by the CEO and they can be fired by CEO so they cannot take part in any special decision regarding CEO compensation. (Claessens \& Fan, 2002) Corporate governance has received attention in recent years because of awareness about the legal procedures to do the task of business. It is stated that increasing volume of research on corporate governance helping people to adopt it and to facilitate the business owners and the stakeholders also. In Asia, the work on corporate governance is increasing day by day and it creating awareness about different concepts related to corporate governance. As we know that woman always face hurdles to achieve the executive seats in the firm. There are very few executive level seats which are covered by women. (Adams \& Ferreira, 2008) Stated that this situation is now near to change because mostly board now interested in hiring female more than male because women are more creative and they also deserve executive level seats.

\section{Theoretical Framework}

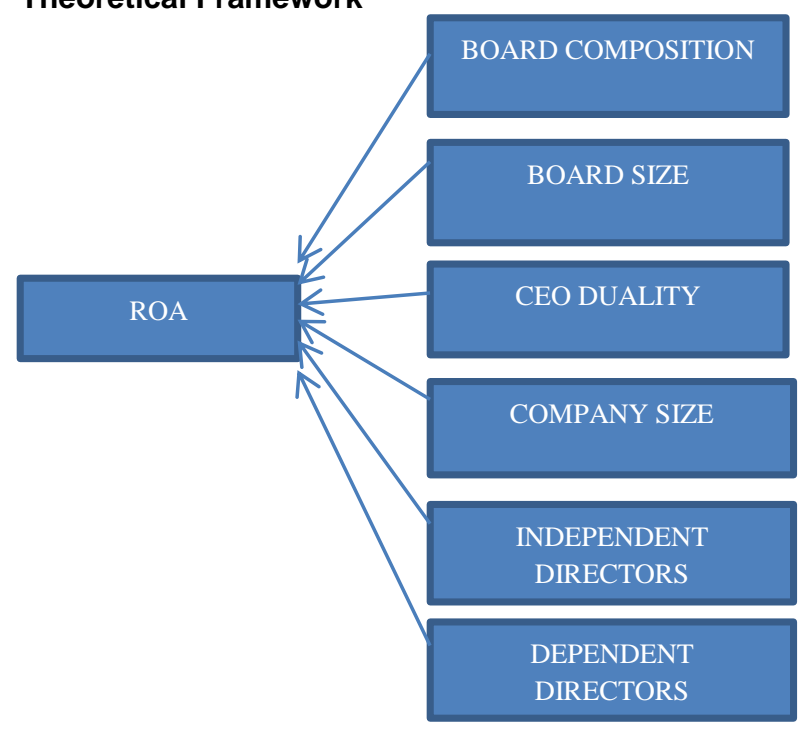

\section{Data and Methodology}

For the purpose of this study, all of the listed pharmaceutical companies of Pakistan were chosen. The companies were identified through the websites of national stock exchange of Pakistan. A total of 9 companies were identified and selected for this study. The annual reports of these companies downloaded from the official websites of the companies. The data is collected for the period 2010-2015.

There are seven variables used in this study. One is dependent variable that is return on asset and other six are independent variables that are: composition of board, company size, CEO duality, board size, independent directors and dependent directors. These all variables are tested through regression analysis and the results are discussed below. 
The Effect of Corporate Governance on The Performance of

Firms: A study on

Pharmaceutical Sector of Pakistan

Abid Rasheed, Hafsa Zaki

$\begin{array}{ll}\text { Variables } & \text { Definitions } \\ \text { Return on Assets } & \begin{array}{l}\text { A ratio that commonly defined as net } \\ \text { income divided by total assets. } \\ \text { It tells about the ratio of independent } \\ \text { and dependent directors of the } \\ \text { company. }\end{array} \\ \text { Company Size } & \begin{array}{l}\text { It is measured by the total assets of the } \\ \text { company. }\end{array} \\ & \begin{array}{l}\text { It is normally concern about that } \\ \text { whether the chairman and CEO is the } \\ \text { CEO duality }\end{array} \\ \text { same person or there are different } \\ \text { persons on different designations. }\end{array}$

Board Size It tells that how many directors are working in a company.

An individual who has no significant personal interests in the company and has no link to a special interest group or stakeholder group.

An individual who has significant Dependent Directors personal interests in the company and who is linked with the internal activities of the company.

\section{Findings}

Table 1

Regression analysis

\begin{tabular}{|c|c|c|c|c|}
\hline \multicolumn{5}{|l|}{ Dependent variable: ROA } \\
\hline \multicolumn{5}{|l|}{ Method: Least Squares } \\
\hline \multicolumn{5}{|l|}{ Sample: 154} \\
\hline \multicolumn{5}{|l|}{ Included observations: 54} \\
\hline Variable & Coefficient & Std. Error & t-Statistic & Prob. \\
\hline $\mathrm{C}$ & -0.259855 & 2.863948 & -0.090733 & 0.9281 \\
\hline BOARD_COMPOSITION & -0.987706 & 0.434048 & -2.275570 & 0.0274 \\
\hline BOARD_SIZE & -0.202050 & 0.815239 & -0.247842 & 0.8053 \\
\hline CEO_DUALITY & -0.671795 & 0.402364 & -1.669622 & 0.1015 \\
\hline COMPANY_SIZE & -0.145196 & 0.121277 & -1.197226 & 0.2371 \\
\hline NED_S & 1.487275 & 0.860150 & 1.729088 & 0.0902 \\
\hline R-squared & 0.204047 & \multicolumn{2}{|c|}{ Mean dependent var } & -2.602576 \\
\hline Adjusted R-squared & 0.121135 & \multicolumn{2}{|c|}{ S.D. dependent var } & 0.943254 \\
\hline S.E. of regression & 0.884280 & \multicolumn{2}{|c|}{ Akaike info criterion } & 2.696353 \\
\hline Sum squared resid & 37.53363 & \multicolumn{2}{|c|}{ Schwarz criterion } & 2.917351 \\
\hline Log likelihood & -66.80152 & \multicolumn{2}{|c|}{ Hannan-Quinn criter. } & 2.781583 \\
\hline F-statistic & 2.461017 & \multicolumn{2}{|c|}{ Durbin-Watson stat } & 1.631136 \\
\hline Prob(F-statistic) & 0.045993 & & & \\
\hline
\end{tabular}

In this study, dependent variable is ROA. The results show that board composition has negative effect on ROA. If board composition goes up by 1 so ROA will goes down by 0.98 . It shows that both variables have negative relationship between each other and relationship is significant. Board size has negative effect on ROA. It shows that both variables have negative relationship between each other and it is not significant because the probability is more than 0.05 . If board size increase by 1 so ROA will goes down by 0.20 . CEO duality also shows the negative relationship between the variables. If CEO duality increase by 1 so it shows that ROA will goes down by 0.67 and it is also not significant because its probability is 0.10 . Company size shows the negative relationship between variables if company size goes up by 1 so ROA will goes down by 0.14 . It is not significant because it is more than 0.05. NED'S shows positive relationship between variable and it is not significant because its probability value is more than 0.05 . if NED'S increase by 1 so ROA will also increase by $1.49 . \mathrm{R}^{2}$ is 0.20 which shows that $20 \%$ variation in ROA is explained by company size, board composition, board size, CEO duality and NED'S. F-Value is 0.04 and it shows that the data is good fit.

The value of board composition is significant and it shows that only board composition has effect on the firm performance and the other variables are not significant and their P-values are more than 0.05 it shows that company size, CEO duality, board size, independent directors and dependent directors has no effect on the performance of pharmaceutical sector.

Model

$Y=\beta_{0}+\beta X_{1}+\beta X_{2}+\beta X_{3}+\beta X_{4}+\beta X_{5}+\beta X_{6}$

$\mathrm{Y}=$ Return on asset

$\mathrm{X} 1=$ Board Composition

$\mathrm{X} 2=$ Board Size

$\mathrm{X} 3=\mathrm{CEO}$ Duality

X4= Company Size

$\mathrm{X} 5=$ Independent Director

X6= Dependent Director 
Model Summary

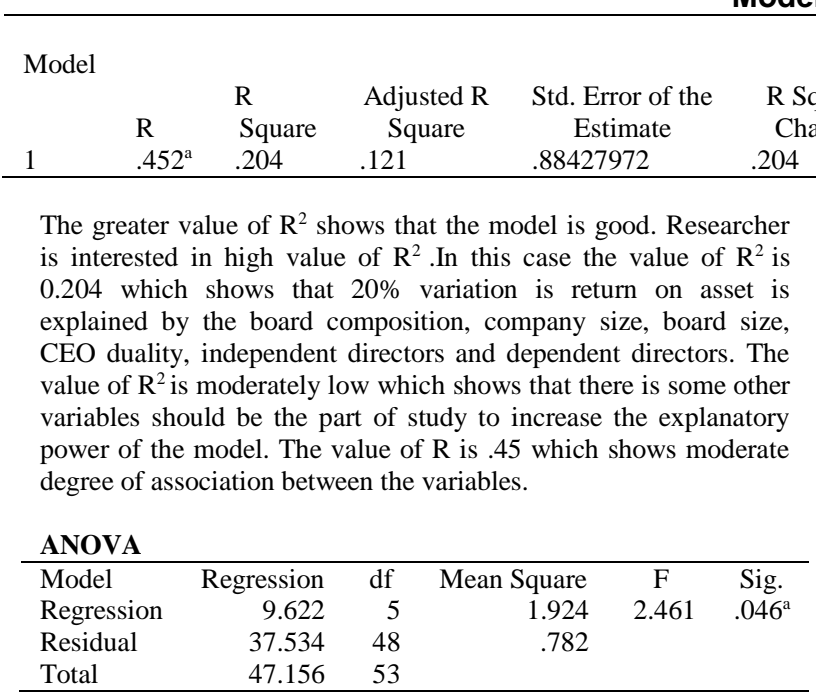

The value of F-statistics is 2.461 and the $\mathrm{P}$-value is 0.046 which shows that the model is significant because the $\mathrm{P}$-value is less than 0.05 .

\section{Discussion}

It can be observed from given results that only one independent variable that is composition of board has significant result which shows that only this variable has effect on the performance firm while other variables which are: company size, board size, CEO duality, independent variable and dependent variable has insignificant values which means that they don't have any effect on the performance of pharmaceutical sector. The data is collected from the annual reports of the listed pharma companies. The data is downloaded from the official websites of the pharmaceutical companies and it is taken from the year 2010-2015. This whole study is done to check the effect of corporate governance on the performance of firm but the results shows that variables don't have effect on the performance of firm.

Pharmaceutical companies playing a vital role in the well-being of the society and as we all knows that corporate governance also has significant importance. This is why I choses pharma sector to check whether the performance of this sector is effecting by corporate governance or not. But results show that there is less significant importance of corporate governance in pharma sector. CEO duality is the big factor in the corporate governance. It guides that there must be difference between the chairman and chief executive so the decision making process will get more refined and flawless because it will be under the supervision of two big authorities but in pharma sector mostly firms are not giving much importance to this factor. In some pharma companies there is only one person is appointed in two designations which is also the alarming situation for them.
Change Statistics

$\begin{array}{lcclc}\text { F Change } & \text { df1 } & \text { df2 } & \text { Sig. F Change } & \text { Durbin-watson } \\ 2.461 & 5 & 48 & .046 & 1.631\end{array}$

For the future development there is need to improve the corporate governance and it is also proven that good corporate governance can attract foreign investors (Rajput \& Bharti, 2015). Pharmaceutical sector should give importance to the corporate governance so it can help investors also to invest their money in this sector, otherwise investors will never get attract from this sector and may be in future pharma sector face some difficulties in development.

\section{Conclusion}

The aim of this article is to analyze the effect of corporate governance on the pharmaceutical sectors' performance of Pakistan. To analyze this, different tests are applied on the nine listed pharma companies of Pakistan but the final results proven that pharma sector should give attention towards the corporate governance otherwise in future maybe they don't get as much development as other sectors will get due to following the principles of corporate governance. This study is done on the latest data of pharma sector and it shows that yet they are not able to understand the importance of corporate governance in firm performance.

\section{Reference}

i. Adams, R. B., \& Ferreira, D. (2008). Women in the boardroom and their impact on governance and performance. Institute Of Economic Research.

ii. Baek, J.-S., Kang, J.-K., \& Park, K. S. (2004). Corporate governance and firm value: evidence from the Korean financial crisis. Journal of Financial Economics, 265313.

iii. Bhagat, S., \& Bolton, B. (2007). Corporate governance a firm performance. Journal of Corporaton Law, 231-274.

iv. Brown, L. D., Robinson, J. M., \& Caylor, M. L. (2007, July December). Corporate governance and firm peformance in India. Research Gate, 1-52.

v. Claessens, S., \& Fan, J. P. (2002). Corporate governance in Asia: a survey. Internation Review Of Finance, 3(2), 71-103.

vi. $\quad$ Core, J. E., Holthausen, R. W., \& Larcker, D. F. (1999). Corporate governance, cheif executive officer compensation and firm performance. Journal of Financial Economics, 51, 371-406.

vii. Crystal, G. (1991). The overcompensation of American executives. In Search of Excess.

viii. Gillan, S. L. (2006). Recent development. Journal of Corporate Finance, 381-401.

ix. John, K., \& L., S. (1998). Corporate Governance and Board Effectiveness. Journal of Banking and Finance, 371-403. 
Abid Rasheed, Hafsa Zaki

x. Mashayekhi, B., \& Bazaz, M. (2008, December).

Corporate Governance And Firm Performance in Iran. Journal of contemporary accounting and economics.

xi. Masulis, R. W., Wang, C., \& Xie, F. (2010, 3 19). The effects of foreign directors on corporate governance and firm performance. Journal of Finance, 52, 1695-1725.

xii. Rajput, D. N., \& Bharti, M. (2015). Shareholder types, corporate governance and firm performance: an anecdote from Indian corporate sector. Asian Journal of Finance \& Accounting, 7(1), 45-63.

xiii. Yasser, Q. R. (2011, June 3). Corporate governance and performance: A study for Pakistani communciation sector. International Journal of Trade, Economics and Finance, 2(3), 204-211. 